\title{
Transition from the old to the new: lessons learned in the Israeli Histadrut during the Ramon leadership
}

\begin{abstract}
The old Histadrut was founded as a welfare agency, employed about one-third of the Israeli labour force and was the dominant health service provider, being primarily funded by insurance premiums. A socialist entity, the Histadrut was politically and economically linked to the Labour Party which helped fund it while in government. In 1994, a new leader - Haim Ramon - was elected. He transformed the Histadrut into a confederation of autonomous labour unions, selling off Histadrut enterprises and assets to private investors and severing all political ties. The Histadrut underwent a downsizing and focused on trade union goals. A year later, Ramon resigned from the Histadrut. This article explores the transformation and Ramon's political objectives and orientation, concluding that the Histadrut, already in a position of corruption and weakness, and experiencing a loss of political and organisational legitimacy, has been heavily damaged by this period. Trade unions may be going through problems of downsizing and decline but the key to survival is a leader who believes in the concept of empowerment.
\end{abstract}

Keywords: union leadership, downsizing, privatisation, goal transformation

\section{Introduction}

The Histadrut (General Federation of Workers in Israel) was founded in 1920. After decades of stability, it underwent organisational change when, in 1994, the Labour Party relinquished its leading role and an outsider - Haim Ramon - was elected to run the organisation. He initiated a process of downsizing and privatisation. In 1995, as Health Minister in Peres's government, he enacted the National Health Law. Under the new law, the Histadrut no longer owned Kupat Holim Clalit, its health services provider and Israel's largest health management organisation. With taxpayers' money now going to the government to provide health care services, rather than to the health management organisations, the Histadrut lost its main source of income, increasing its financial difficulties (Ramon, 1995) and, ultimately, leading to total privatisation (Reinhart, 1999).

The purpose of this research is to understand and explain the behaviour of Ramon's policy: how did his leadership affect the goals of the Histadrut in the course of its transition from a super-organisation dominating most of Israeli society to a confederation of labour unions. 


\section{Historical background to case study}

The Histadrut was established in 1920 by Jewish pioneers with the aim of organising economic activity in pre-state Jewish society. It founded factories as well as organisations to help the new settlements, such as Bank Hapoalim ('Workers' Bank') and Kupat Holim Clalit which provided health care services. Many of the founders of the Histadrut were not religiously observant, but the Histadrut made special efforts to establish strictly kosher kitchens to meet the needs of devout workers. In addition, it established retail stores open to the general public - not only to Histadrut members - as well as construction companies and social aid services (Bartal, 1989; Shapiro, 1977).

The labour unions were concerned with the well-being of workers. At the same time, as the owner of Koor and other manufacturing and service enterprises, the Histadrut also represented the interests of management - that is, of itself(Greenberg, 1993).

Before the establishment of the state of Israel in 1948, the Histadrut was the administrative mechanism of the dominant party - MAPAI (the Hebrew acronym for the Workers' Party of Israel). The organisation recruited political support using resources it received from the Zionist Federation. After the establishment of the state, many Histadrut leaders held high positions in government, adding another element of conflict this time between law-makers and the financially powerful and influential Histadrut (Shapiro, 1977).

In the 1950s, Histadrut Secretary Pinchas Lavon wanted to increase the power of the organisation. However, his policy contradicted Prime Minister David Ben-Gurion's national perception, which had the goal of controlling all national organisations and supervising their actions (Horowitz and Lisak, 1977; Greenberg, 1993).

The Histadrut, government and MAPAI were strongly inter-linked. MAPAI was dependent on the Histadrut which helped it recruit new members, resources and voters by supplying them with work and accommodation. The Histadrut needed the government's help to sanction its activities and the government was dependent on the party regarding wages.

The Histadrut dominated the Israeli economy until the mid 1970s. In the 1960s and early 1970s, it enjoyed strong government support, especially from Minister of Finance Pinchas Sapir. However, the status of the labour unions changed when the right-wing Likud was elected to government in 1977. Likud aimed to weaken the Histadrut and, under the Likud government, the Histadrut did not receive resources and aid in its crisis. By then, the Histadrut was debt ridden, its assets dropping in value and some even collapsing. Between 1980 and 1994, the Histadrut began selling off its factories to cover losses and repay its debts (Greenberg, 2004).

There was a major change in 1994, when an outsider - Haim Ramon - was elected to run the Histadrut. Ramon created a coalition which brought together most of the parties within the Histadrut - the Labour Party, Likud, SHAS (a religious party) and the Communist Party. However, he served as Chair for only one year. Following the assassination of Prime Minister Yitzhak Rabin in 1995, Shimon Peres (Rabin's successor) nominated Ramon as Minister of Health.

In that post, Ramon initiated a national health insurance system which passed into law on 1 January 1995 (Admati, 2001). The new law separated the Histadrut from health 
care services, which had been the organisation's primary money maker since most of its resources came from membership payments for health services.

\section{Theoretical framework}

Globalisation and capitalism affect trade unions worldwide as they carry with them the distribution of similar patterns of mass production, the sale of the same products everywhere and a culture of conspicuous consumption (Iranzo and Thanali, 2002; Rainnie, 2006). In the 1970s, conservative governments rose to power in Europe, the United States and Israel, and all implemented budget cuts that were detrimental to national welfare policies (Margalit, 1994). Liberal economies go hand-in-hand with conservative government and bring about less national and public support (Held and McGrew, 2002).

Capitalist policies damaged workers' rights by giving a free hand to big corporations. One of the outcomes of a liberalised economy is unemployment, as unions are powerless and unable to protect workers (Western, 2002). Trade unions try to fight globalisation by become stronger and more competitive, and also by creating international unions (Dabscheck, 2003; Rainnie, 2006).

In the past (Margalit et al, 2000), union representatives had signed co-operation agreements with government and employers. In recent years, however, employers have broken those agreements with the aim of withdrawing from co-operative arrangements and benefiting the rich and powerful elites instead. Trade unions today are not a part of the decision-making process in factories and the owners alone determine wages and benefits. These market conditions demonstrate the level of vulnerability and uncertainty in workers' lives, as well as providing an indication of the decline of unions (Kiely, 2003).

Mergers and acquisitions in banking, oil and communications have led to unemployment in England, Canada and Japan. In the past, unions took care of their members. With the shift to greater government involvement, however, workers' interests are no longer adequately represented (Mangum and Mangum, 1993).

Employers are hostile to unions and workers who join unions are subject to dismissal (McCartin et al. 2005). Unions are suffering from organisational decline and crisis: they cannot recruit new members while many older members are leaving (Western and Craver, 1997; Forrant, 2002; Weil, 2005; Banciu, 2009).

\section{Union leadership}

Union leaders play a significant role in the struggles being waged between government and employees all over the world to improve the salaries of, and support for, workers (Latham and Ditzler, 2010; Riddell, 2000; Melling, 2004; Kimmerling, 1995). The struggles of the leaders are influenced by their personalities as well as by the political orientations of factions within different unions which are known to be significant with regard to the growth of white-collar unions (Melling, 2004; Edmund and Kelly, 1990).

However, other commentators (Behrens et al. 2004; Kelly, 2005) have pointed out that, sometimes, leadership activity bringing about union revitalisation has simply cor- 
responded with periods of membership growth. Revitalisation can occur in dimensions other than membership by the embrace of economic power and the achievement of improvements in pay and benefits, and by the influencing of public policy (Stirling, 2005).

Most union leaders tend to have left-wing political views. In India, trade union leaders struggled after World War I against the governing Congress Party to improve oppressed workers' conditions, fulfilling their union's aims by joining the left-wing Communist Party (Rao, 2004). In Europe, too, Communist miners' leaders in Poland and Germany - Willi Agatz, Edward Gierek and Arthur Horner - struggled to improve miners' incomes; they were revolutionary trade unionists pursuing strategies to restore the position of miners by defending them from cuts and preventing their dismissal (Fishman, Prazmowska and Heith, 2006).

Union leadership is usually dominated by left-wing activists (Taylor and Bain, 2003; Simms, 2007) in - for example - Britain's National Union of Rail, Maritime and Transport Workers. Their orientation has led the leaders militantly to oppose privatisation in general and to express grievances over pay and conditions in particular (Darlington, 2009).

Darlington (2009) emphasises the role of union left-wing activist leaders in creating material conditions for labour by negotiating with employers. Their militant attitudes may lead to conflict with employers as a result of their stimulation of workers' awareness of grievances and their potential for collective action. Union leadership can coordinate workers by proposing and encouraging cohesion among them. Their effect is to translate a political agenda into collective action in the form of strike activity or even the use of strike threats as a bargaining strategy.

Strikes tend to enhance trade union solidarity. This has happened all over the world, including in the Polish port of Gdansk during 1980 (Kimmerling, 1995); the retail sector in South Africa, Zambia and Mozambique during the 1990s after the democratisation process (Miller, 2005); and during the 1981 strike of American air traffic controllers (PATCO) (Shostak, 2006).

On the other hand, there have been union leaders who have been more right-wing in their orientation. In the United States between 1880 and 1895, John McBride was President of the United Mine Workers of America (UMWA). His approach was rooted in the American Republican tradition that supported capitalism and saw labour as a means of economic independence for workers, while accepting government liberal right-wing policy (Pierce, 2000).

Union leaders are also struggling for the survival and maintenance of their organisations. In recent years, Australian union leaders have been fighting against anti-union and anti-working class laws after the processes of globalisation and capitalism had created a negative climate for union activity in Australia. The leaders have been seeking to prevent the downsizing of their unions by finding common ground among workers, government and employees (Rainnie, 2006). Additionally, other union leaders in America, Europe and Korea are trying hard to protect union organisation by promoting reform, increasing organised activities and recruiting new members. These steps are contributing to the strength of unions (Willis, 1988; Pierce, 2000; Weil, 2005; Banciu, 2009) and creating intra- and inter-organisational solidarity (Chen, 2010). 


\section{Research method}

This research employed qualitative methods via the comparison of data from two periods: the first while Haim Haberfeld was Chair (1992-1994); the second the period of organisational change under the leadership of Haim Ramon (1994-1995).

Two methods of data collection were used: document analysis and interviews.

\section{Documents}

Most of the documents were collected from the Lavon Institute - the archive of the Histadrut. They included the union's rules and regulations and the Minutes of the Central Committee and Secretariat as well as the Minutes of union conferences. I analysed the reports of the Histadrut Inspector and supplemented the information with newspaper articles describing events at the various conferences.

\section{Interviews}

Some of the interviews were open. In these, interviewees were asked general questions and a friendly conversation ensued. In most cases, however, the interview was planned, focused and followed a structured questionnaire adapted to each interviewee.

The interviews were conducted between 2005 and 2007, and numbered a total of thirty people, representing a wide range of Histadrut activists - union leaders, leaders of local branches, Knesset members and Histadrut administrators. Among those I interviewed were Haim Ramon, the Histadrut Chair who had initiated the period of organisational change; MK (member of Knesset) Haim Oron, Treasurer of the Histadrut partly under Ramon during 1995-1996; former MK Yossi Beilin, one of 'Ramon's Octet'; and attorney Gideon Ben-Israel, who represented pensioners and who had held many administrative positions in the old organisation.

Other interviewees were Monia Admati, who had held several positions in the old Histadrut; Meir Gat, who had been an assistant to Haim Haberfeld; Eli Nachmias, who is still the Treasurer of the Haifa branch; Danny Gutwein, who was Peretz's personal advisor when he chaired the Histadrut; Shula Cohen, head of the Carmiel branch; Dalia Kalishevsky, who held many leading administrative responsibilities; Pini Kabalo, who represented the Bet She'an area in the union; Ilan Asia, who was a representative in the old organisation; Efraim Zilony, Chair of the professional union; Shlomo Avitan, Chair of Bina (Histadrut's parliament); and Haim Zlotnik, who had been Haberfeld's assistant.

I collected my information slowly and carefully, cross-checking to validate the information obtained from each interviewee against other sources because most of the interviewees were very subjective. All those whose names are listed above gave permission to be quoted. Others asked to remain anonymous. All interviewees had participated directly in the organisational events which they reported to me. I found my interviewees by the 'snowball method' whereby each Histadrut member that I interviewed referred me to others.

In addition to the interviews, I read books written by members of the union and the Labour Party. Monia Admati's From the Old Histadrut to the New One proved a valuable source of information. Admati was personally acquainted with many union leaders, 
and they agreed to be quoted in his book based on these relationships. I derived information from this text about several people who refused my request to interview them. Gideon Ben-Israel's autobiography, The Fighter and the Dreamer, relates to union events and problems. I was aware of the subjectivity of these sources, but they helped me understand organisational processes. Yitzhak Greenberg's book about the collapse of the Histadrut economic arm, Hevrat Haovdim (the Society of Workers), supplied me with important background material on the organisation.

The basis for analysing these findings was an examination of internal organisational processes and external effects. The analysis is chronological and is subjective in that it is based on the opinions of interviewees. This chronological analysis enabled me to follow the leadership policy in the new Israeli labour union by connecting internal and external factors.

\section{Findings}

\section{The goals of the old Histadrut}

It was Haim Ramon who transformed the old Histadrut into the new organisation; his policies changed the organisation's whole system of goals. Firstly in this section, the old goal system will be presented, followed by the new policy and then a comparison of the two.

Up until 1994, the goals of the old Histadrut (Hevrat Haovdim, 1990) were achieved by the Hevrat Haovdim, the economic arm through which it supplemented peoples' means of livelihood and work; improved workers' living conditions; advanced peripheral areas; resolved housing problems; and created economic activity. The Histadrut operated in many fields: manufacturing; construction; settlements and agriculture; cooperatives; transportation; finance and development; culture; and activities in Arab and Druze villages. The Histadrut achieved its goals by several means.

\section{Manufacturing}

Histadrut factories were handled by Hevrat Haovdim. The manufacturing segment of the Histadrut included Koor Industries, a conglomerate operating in co-operation with kibbutz factories. Koor's 280 plants were diversified - electronics; electricity; plastics; metals; chemicals; and food. The waves of immigration during the 1950s influenced the Histadrut to establish a new organisation - Ti'us (Industry), with the intention of providing employment in peripheral parts of Israel.

\section{Agriculture}

Tnuva (Produce) was the marketing organisation for agricultural produce; it bought products from farmers and distributed them for sale to the public.

Building and constructing

Solel Boneh (Paver-Builder) was the Histadrut's construction arm. It was founded in 1924 and constructed roads, ports and power plants, both for the military and civilian purposes. 
Co-operatives

The Histadrut set up public transportation co-operatives (Egged and Dan), as well as a co-operative of bakeries and another for building materials.

\section{Marketing}

Food marketing was conducted through chains of supermarkets and hypermarkets. Hamashbir was a department store chain for consumer goods owned and run by the Histadrut (and later renamed Hamashbir Lazarchan).

Finance and insurance: Bank Hapoalim (Workers' Bank)

This was the financial body of Hevrat Haovdim. The Bank was established in 1921 and has supplied banking services from pre-state days until the present day.

In addition, Hasneh, an insurance company, was established in 1931.

Culture and education

The 1924 Hevrat Haovdim constitution called for:

Establishing a book publishing house and newspapers and building schools, libraries, theatres and institutions for education and culture. (Histadrut, 1990)

Berl Katznelson, a prominent Histadrut leader, founded the daily newspaper Davar and the Am Oved publishing house. The Histadrut established several other publishing companies with the participation of Tenuat Hakibbutzim (the overall body of kibbutzim affiliated to MAPAI).

\section{Education}

The Histadrut provided technological education for workers, administrative staff and young people. It had schools nationwide ${ }^{1}$ and these provided vocational training for industry, mechanics and office work. It held special classes for adults who wanted to complete their studies and receive a high school matriculation diploma, as well as enrichment courses on the history and geography of Israel. It also promoted sporting activities through Hapoel (The Worker) sports clubs.

\section{Unionisation}

The Histadrut, being a union, fought for workers' benefits. It sought to improve working conditions and provide help and support to poor workers. The labour unions negotiated collective arrangements with the government and initiated welfare and social legislation, while the Histadrut itself provided welfare and retirement services. The Histadrut convention (Histadrut, 1994) listed its goals as ensuring welfare rights through legislation and fighting for full employment and fair wages.

1 www.histadrut.org.il; www.mof.gov.il/bachar. 
Health care

When the Histadrut was founded in 1920, it was with the vision of being not only a union but a provider of services for workers. This encompassed medical services. Kupat Holim (the Histadrut health management organisation) provided a large variety of medical services through psychiatric services, local branches of medical clinics, laboratories, and testing and examination facilities (Shvarch, 2002, 2008).

Social services

Dor LeDor (Generation to Generation) ${ }^{2}$ was the fund created to provide social services for Histadrut members. Its duties were helping elderly people, widows, widowers and orphans. Benefits were intended for those on low incomes who had lived in Israel for thirty years or more.

Pensions services

The first such fund, Mivtahim, was established in 1954.

Assisting elderly people

Mishan, the organisation for assisting the elderly, was established in 1931. Mishan retirement residences are now home to 4300 people and the organisation also operates a geriatric hospital. ${ }^{3}$

Culture, sports and leisure for workers

The Centre for Culture and Sports began its activities in 1975. The Centre operates six sports and recreation facilities in various parts of the country.

Women's advancement and care

$\mathrm{Na}$ 'amat was established in 1921 to promote women's rights, provide legal aid for problems in the family and workplace, and care for abused women and victims of sexual harassment. Na'amat encourages women to acquire education, supports single mothers and assists them with day-care facilities and legal advice (Histadrut, 2002).

Development of the Arab and Druze villages

In 1983, Hevrat Haovdim established a special unit for the development of Arab and Druze villages. Under this programme, the Histadrut built residential units, opened large stores and delivered Kupat Holim healthcare services. ${ }^{4}$

2 Interview with Ilan Vikelman, member of BINA (the representative body of the Histadrut), 18 May 2005.

3 www.histadrut.org.il.

4 www.histadrut.org.il. 
New policy in the new Histadrut under Ramon

When Haim Ramon was elected to chair the Histadrut, he created changes in the union organisation. Ramon wrote:

When I was elected in July 1994, the Histadrut was in worse shape than I imagined. Its stagnation had severed it from society. I initiated reforms to rebuild and change the Histadrut, to offer a genuine answer to its members. The Histadrut had been managed politically and nominations were political. This inefficiency brought about many debts and the debts were the reason for selling off Histadrut assets. (Ramon, 1994-1995)

Selling Histadrut assets - a process of privatisation

Ramon accelerated the privatisation policy and, in 1995, it was decided that Hevrat Haovdim would sell $22.5 \%$ of its assets in Koor Industries to the American company Shamrock for $\$ 252 \mathrm{~m}$. Following this transaction, two other companies were sold Hasneh Insurance and Ti'us ceased to exist, having been sold to entrepreneurs Yuli Ofer and David Amar. Hasneh properties were sold to two other insurance companies - Migdal and Clal Insurance - for \$185m. In 1996, one of the Histadrut construction companies (Shikun \& Binui) was sold to Harrison Investment (Greenberg, 2004).

Other businesses were also sold out - Hamashbir Lazarchan stores and Arkia airlines, both with $50 \%$ ownership, as well as supermarket chains. The Histadrut sold its service companies, among them Histour (a tour operator), Matara (human resources), Sifri (publishers) and Yachin Hakal and Haargaz, both transportation companies. ${ }^{5}$

The result of the sale of medical facilities (clinics and hospitals) was that the settlement between the Histadrut and Kupat Holim helped cover Histadrut's debts of NIS $8 \mathrm{~m}$ (about \$2m). By 1994, the Histadrut had debts totalling \$600m. Ramon indicated that the Histadrut's Kupat Holim was in total crisis and that many insured people had left to join other health management organisations, such as Maccabi. The Histadrut sold all the property of Kupat Holim to the state and, as a headline in the financial newspaper Globes stated on 2 July 2001:

The State's Gift to the Histadrut: A NIS 200 Million Tax Exemption for the Sale of Kupat Holim.

MK Haim Oron, who served as Histadrut Treasurer in 1994-1995, told me:

The Histadrut had a huge administration without a source of funding. The organisation had used the money that was delivered to Kupat Holim, which was in debt for $\$ 1.5 \mathrm{~m}$, because the organisation had used its money for Histadrut political aims. In the old Histadrut, some members thought the organisation could keep the clinics and hospitals and also cover its debts.

Kupat Holim needed an immediate $\$ 210 \mathrm{~m}$. It had run out of medication and the government decided to close it down. Haim Haberfeld (the former Chair) said:

We stole money from Kupat Holim and the money was delivered to other Histadrut institutions; when we tried to correct it, it was too late. (Admati, 2001: 67-68)

5 www.histadrut.org.il. 
Ramon, the new Chair, said:

The role of the Histadrut in the past was to rob Kupat Holim of its money. Some 30-40\% of Kupat Holim funds financed Histadrut needs. Members of the Histadrut wanted health care services, not Histadrut services.

Ramon said that his duty was to implement justice for the members of Kupat Holim:

Kupat Holim did not incur losses. The losses were caused by political nominations in the Histadrut, whose 4000 employees were engaged - directly or indirectly - in political activity.

Ramon referred to the Histadrut as 'the sinking Titanic' (Ramon, 1994-5).

According to Meir Gat, Haberfeld's assistant:

Kupat Holim became corrupt, employing large numbers of unnecessary people for political reasons. There was a lot of talk about instituting reforms in Kupat Holim but nothing was done. The taxes did not cover expenses.

Gat said that most Histadrut employees were against the reforms, which called for a massive reduction in administrative positions. Similar ideas were expressed by Efraim Zilony, Chair of the professional union:

Ramon's actions were based on political views rather than economic ones. He said that the new body would be devoid of political identity. But he actually wanted to replace the old workers with his supporters.

Zilony thought that the new leaders had not bargained with the state after delivering most of its assets and that the Histadrut still remained in debt. Eli Nachmias, Treasurer of the Haifa branch, criticised Ramon's privatisation process:

In the past, the Histadrut had 4000 employees. He [Ramon] laid off almost $75 \%$ of the administration, a move unprecedented anywhere. Ramon gave very generous retirement settlements to workers and, by doing so, created heavy debts for the organisation. Ramon gave the state a present of 100 clinics and 15 hospitals and created a debt of 400 million dollars. The Histadrut relinquished 12 expensive buildings in Haifa and Tel Aviv and, even with that, its debts were not covered.

Like Zilony, Nachmias also accused Ramon of acting in a political fashion. Most of the interviewees claimed that, in every union, management should want to empower the organisation, not weaken and destroy it. Ramon, in contrast, viewed labour unions as archaic and redundant, and his political position was close to right-wing Labour Party circles, including those of Prime Minister Rabin. In this view, Ramon and Rabin were acting together out of mutual interest.

Ramon and his 'Octet' (a group of eight young party members who became members of the Israeli parliament - Yossi Beilin, Avrum Burg, Yael Dayan, Amir Peretz, Hagai Meirom, Nissim Zvili and Nawaf Mazalha) aspired to wield greater power in 
the Party, but the old guard - in both the party and the Histadrut - were blocking their path. Within the Labour Party, Rabin was battling with the Peres faction, many of whose members worked for the Histadrut. According to MK Yossi Beilin and Meir Gat, Ramon and his group were identified with Rabin's faction.

Professor Danny Gutwein, who was consultant to Amir Peretz, former Chair of the Histadrut, explained that Ramon's moves toward privatisation expressed his identification with the interests of capitalists in Israel:

Ramon saw the Histadrut as a problem. He came with views of middle-class morality and participated in the policy of privatisation in Israel. The policy of the labour unions was to serve the poor and establish a welfare state. He [Ramon] and Prime Minister Rabin acted out of the same interests; they saw the Histadrut as interference, and wanted to weaken the labour unions.

Haim Oron justified privatisation:

All Histadrut institutions were bankrupt. The construction firm Shikun \& Binui had to sell Histadrut property. Buildings were mortgaged to banks. The Histadrut newspaper Davar had large debts after the Histadrut invested a lot of money in it; the management put 5 million dollars in the newspaper, but eventually it collapsed and was closed.

Other Histadrut institutions were bankrupt as well. In my interview with him, Eli Nachmias, Treasurer of the Haifa branch, told me that the fifteen lending libraries were all closed down. The collapse of the libraries symbolised the general condition of the Histadrut.

The pensions fund of the Histadrut had accumulated debts of NIS 10m; Ramon announced that the fund would not be able to pay pensions to its 600000 insured members and that the Histadrut and the government would work together to seek a solution. The Histadrut began a process of downsizing and laid off 1600 people. $^{6}$

Netanyahu, as Minister of Finance, established the Bachar Committee that dealt with the implications of the privatisation of the pensions fund. ${ }^{7}$ On 29 May 2003 the Knesset passed a law that forced the sale of the fund, now heavily in debt, to the private sector. The Ministry of Finance managed the fund temporarily until its sale to private owners. This process was forced on the Histadrut, in spite of its opposition. One of the interviewees told me:

The pensions fund had a lot of assets. The Ministry of Finance forced the Histadrut to sell its assets and to put the money in members' accounts.

An interviewee from the Zefat branch told me that, following the 2003 legislation, the Histadrut sold most of its pensions fund, keeping only 'the central pensions fund of the Histadrut'.

Histadrut sports services were also privatised. In 1994, the 17th Histadrut Conference had decided to reform the sports system. According to this decision, public leisure

6 Interview with Yoav Klein, Chair of the professional union at the Carmiel branch, 25 May 2005.

7 www.mof.gov.il/bachar. 
sports activities would continue operating (but professional sports teams were to be sold to public or private enterprises). Payments for any sports clubs or facilities were to be made directly to the sports team and not through Hapoel, the sports department of the Histadrut. Hapoel was now in charge of establishing policies, consulting and organising sports events for the public, but was stripped of all its managerial responsibilities.

Eli Nachmias (the Treasurer of the Haifa branch) told me that the new Histadrut stopped the financing of professional sports, while a new Common Council for Sports (Ramon, 1994-1995) was established. The professional Hapoel sports teams were sold to pay off a \$2m debt. The national league football team Hapoel was sold to two entrepreneurs, Robi Shapira and Yoav Katz; the Tel Aviv football team was sold to the entrepreneur Lev Leviev.

In addition, many local branches of the Histadrut were closed. Of the 937 branches that had existed before 1994, only $20 \%$ remained. Here, again, most of the employees were laid off.

Goal transformation in the new Histadrut: comparing the old goal system with the new

The crisis in the old Histadrut led to a radical change in the organisation's goal system. Meir Gat said that the new Histadrut lost its special nature as, in the past, the organisation had provided general services to the entire Israeli population. The Histadrut had been deeply involved in national social and financial affairs and was instrumental in determining government policy regarding incomes, wages and the standard of living. According to Gat:

The Histadrut participated in negotiating with the government about workers' incomes and welfare services. It was a main tool for stabilising the Israeli labour market through its involvement in agreements with the government and with employees. Today, the new organisation does not represent its 600000 workers. The new Histadrut represents only the big unions and its activity is conducted mainly by its professional union.

Histadrut activity was, previously, based on big budgets which gave it a free hand. In Munia Admati's words:

In the past, the Histadrut taught its union representatives, they had legal knowledge. They knew how to appear in labour courts. The Histadrut had a school for activists and it was financed by its former Chair, Kaisar. When I left the organisation, there were no budgets and no activities.

One of the chairs of the professional unions in northern Israel recounted how goal displacement had affected Histadrut activity:

The change is in the activity of the professional union. In the past, membership of the Histadrut was taken for granted, but this is no longer the case. Today, I have to pursue each member to please them. In my duties, I take care of members' problems and when they address me when they have professional problems, this is the time to recruit them to the union. I have to go from one factory to another to convince them that the union is supplying various services: legal aid; 
professional aid; and improvements in working conditions. Mostly, the workers are afraid to address the Histadrut, because their employers are against it.

I received similar information from other interviewees, all of whom emphasised the special role of the professional union.

\section{Discussion}

Ramon, the new Histadrut leader, initiated privatisation and the downsizing that affected goal transformation across the whole organisation, but there were also external causes that contributed to these processes. Israeli society had become more ideologically right-wing and politics made the organisational environment hostile to the Histadrut. The new atmosphere meant that fewer funds were channelled from the government to the Histadrut, and the lack of resources forced the organisation to implement changes that transformed its goal system. The old Histadrut leadership, before Ramon, ignored the organisational problems. They had managed, up to 1994, on a political basis without any consideration of the economic costs.

The old Histadrut spent large amounts of money and Haberfeld, its former leader, was reluctant to cut expenditure. He did not want to dismiss members of the Histadrut because they and their families would not support them in future internal elections. The Israeli Labour Party controlled the Histadrut and was interested in the continued existence of Histadrut factories: by providing employment, the Histadrut and its patron the Labour Party - earned public support. Labour leaders were, consequently, concerned with being re-elected in the general election, even at the price of the maintenance of organisations and factories that were inefficient (Greenberg, 2004).

Managerial failure and the resultant bad publicity undermined the legitimacy of the Histadrut. Ramon's policies affected the processes of privatisation and downsizing. When he left the union, he initiated the 1995 national health care legislation which cut the Histadrut off from its main source of financing, and the resource problem became a major threat to its existence.

The economic, political, ideological and sociological environment had changed (Bozman, 2002); Israeli society became more capitalist and right-wing governments did not, as a result, protect Histadrut assets (Held and McGrew, 2002). In pre-state days and up to 1977, MAPAI and other labour parties in government had taken care of Histadrut interests. In contrast, the Likud government of 1977 acted with hostility towards the Histadrut (Greenberg, 2004). The result was that the organisation suffered from decline and struggled for its survival, as did other unions in the world (Western, 1995; Craver, 1997; Forrant, 2002).

Ramon deliberately directed the goal system towards his ideological and political ends and needs. Ramon decided to sell most of the Histadrut's assets in order to cover its debts, out of the conviction of his right-wing views. Ramon did not try to save the Histadrut from privatisation; he was Chair of the Histadrut for only one year but, during this short period, he managed to dismantle most of the assets of the organisation. A young leader, Ramon worked alongside Rabin's coalition in the Labour Party. He and Rabin were aware of the negative image of the Histadrut and they thought that the connection between the Party and the Histadrut would damage them in their election 
campaign. The Israeli public despised the Histadrut for its corruption and inefficient management, and Ramon had a public mandate to destroy the organisation.

Among the Israeli public, there was much hostility toward the Histadrut - the organisation had the image of being populated with parasites who did not work and who spent their time drinking tea. Ramon thought the destruction of the Histadrut would serve his political aspirations. Both ideologically and politically, he was close to Yitzhak Rabin, and this positioning gave him tacit permission to destroy the Histadrut.

Ramon was a different union leader. When comparing the literature, we see that most union leaders identify with left-wing beliefs (Kelly, 1998; Darlington, 2009; Taylor and Bain, 2003; Heery and Conley, 2006; Simms, 2007; Rao, 2004), whereas Ramon's ideas were right-wing (Pierce, 2000). He promoted the processes of privatisation and his policies led to the loss of the majority of the assets of the Israeli labour union. His leadership was unusual: most union leaders protect and fight for the rights of union members (Riddell, 2000), or strive to empower their organisation (Melling, 2004; Willis, 1988; Pierce, 2000; Weil, 2005; Banciu, 2009) or to prevent the downsizing of the union (Rainnie, 2006). Ramon, in contrast, wanted to destroy the union and he acted against the interests of the members and leaders of the Israeli labour unions. He thought that the animosity of Israeli society towards the Histadrut would serve his political goals. Ramon saw the union as a means to his end: becoming leader of the Israeli Labour Party. However, his policy backfired: his actions caused many union members to lose their jobs, they hated Ramon and, finally, he left the Labour Party.

Ramon did not defend union members as most union leaders would do. Conversely, he dismissed many union members and encouraged privatisation, and this harmed cohesiveness and solidarity among the union's workers (Darlington, 2009; Chen, 2009). Ramon manipulated the labour unions and used the Histadrut's goal system towards his own needs.

His actions were motivated by ideology; Ramon represented the right-wing coalition in the Party, yet his orientation had a considerable effect on the Histadrut goal system: Ramon worked hard to diminish and minimise its activities.

We can understand the hostility of union members and employees towards privatisation, as Ramon's reforms minimised their organisation and caused massive downsizing in Histadrut jobs. They saw their organisation being destroyed and, although Ramon's measures were necessary, they were not able to accept them. The Histadrut managers interviewed for this project suffered from the changes; their views were socialist and they were very subjective regarding the process. In a capitalist environment and a time of globalisation, the organisation had to adjust to the new conditions.

The old organisation and its leaders ignored the changes and did not implement the necessary steps, causing the organisation to collapse (Margalit, 1994; Greenberg, 2004). Ramon's privatisation policy forced the Histadrut to focus on its trade union industrial goals.

This case study reveals processes that are similar to those applying to other trade unions worldwide as a result of the processes of downsizing and decline (Dolvik and Waddington, 2004; Humphrey, 2000; Voss and Sherman, 2000; Rainnie, 2006). Nevertheless, this case study is unique and different from that of other union organisations 
because of the attitude of Ramon, the leader, whose policy actions were contrary to the interests of the members of his union.

Lessons learned: conclusions

1. a union organisation needs public support; when it loses legitimacy it has difficulties in recruiting resources from society. The result is a threat to its survival

2. the old Histadrut suffered from inefficient management which ran the organisation on a political basis

3. the old leadership brought about bankruptcy, with the management refusing to conduct the changes that were necessary

4. the old Histadrut's service organisation had reached a point of total collapse, giving the new elected leader a mandate to sell assets

5. in a capitalist environment and at a time of globalisation, union organisations must adjust to the new environmental conditions

6. privatisation policy can lead to changes in union organisation: downsizing and goal transformation

7. unions need a leader who believes and identifies with their goals - in these circumstances, he acts to empower the organisation. This is in contrast to the Histadrut case, since its leader, Ramon, removed most of its assets and minimised the activity of the Israeli labour unions.

\section{References}

Admati, M (2001) From the Old Histadrut to the New One Tel Aviv: Histadrut Publications [in Hebrew].

Banciu, A (2009) 'Institutional Reform in the European Union' Geopolitics, History and International Relations 1(2): 139-143.

Bartal, G (1989) The Histadrut: Structure and Activities Tel Aviv: Histadrut Publications [in Hebrew].

Behrens, M, K. Hamann and R. Hurd (2004) 'Conceptualizing Labour Union Revitalization' in C. M. Frege and J. E. Kelly (Eds.) Varieties of Unionism: Strategies for Union Revitalization in a Globalizing Economy New York: Oxford University Press, pp. 11-19.

Bozeman, B (2002) 'Public Value Failure: When Efficient Markets May Not Do' Public Administration Review 62(2): 145-161.

Chen, J. J (2009) 'Book Review' in D. Suh and Tu-wǒn Sǒ Political Protest and Labor Solidarity in Korea: White-Collar Labor Movements after Democratization (1987-1995) Taylor \& Francis.

Cornfield, D. B and H. J. McCammon (2003) 'Revitalizing Labor: Global Perspectives and a Research Agenda' Research in the Sociology of Work 11: 1-20.

Craver, C. B (1997) 'Mandatory Worker Participation is Required in a Declining Union Environment to Provide Employees With Meaningful Industrial Democracy' George Washington Law Review 66: 135-171. 
Dabscheck, B (2003) 'International Unionism's Competitive Edge: FIFPro and the European Treaty' Industrial Relations 58(1): 85-108.

Darlington, R (2009) 'Leadership and Union Militancy: The Case of the RMT' Capital and Class 99: 3-32.

Dolvik, J. E and J. Waddington. (2004). “Organizing Marketized Services: Are Trade Unions Up to the Job?" Economic and Industrial Democracy, 25(1): 9-40.

Fishman, N, A. J. Prazmowska and H. Heith (2006) 'Communist Coalmining Union Activists and Postwar Reconstruction, 1945-52: Germany, Poland and Britain' Science \& Society 70(1): 74-97.

Forrant, Robert (2002) 'The International Association of Machinists, Pratt \& Whitney, and the Struggle for a Blue-Collar Future in Connecticut' International Review of Social History 47(S10): 113-136.

Greenberg, L. L (1993) The Histadrut Above All Jerusalem: Nevo Publishing [in Hebrew].

Greenberg, Y (2004) Anatomy of Crisis Foretold: The Collapse of Labor Owned Enterprises in the 80s Tel Aviv: Am Oved [in Hebrew].

Heery, E and J. Kelly (1990) 'Full-time Officers and the Shop Steward Network: Patterns of Co-operation and Interdependence' in P. Fosh and E. Heery (Eds.) Trade Unions and Their Members London: Routledge, pp. 75-106.

Held, D and A. G. McGrew (2002) The Global Transformations Reader Cambridge: Polity.

Histadrut (1990) The Aim is Participation and Involvement in Hevrat Haovdim. Tel Aviv: Lavon Institution [in Hebrew].

Histadrut (1994) Minutes of the Histadrut 17th Convention Tel Aviv: The New Histadrut [in Hebrew].

Histadrut (1995) Minutes Report of the Histadrut Controller 1995 Tel Aviv: Histadrut.

Histadrut (2002) Minutes of Histadrut 19th Convention Tel Aviv: The New Histadrut [in Hebrew].

Horowitz, D and M. Lisak (1977) From Pre-state to the State Tel Aviv: Am Oved [in Hebrew].

Humphrey, J. C (2000) 'Self-organization and Trade Union Democracy' Sociological Review 48(2): 262-282.

Iranzo, C and T. Patruyo (2002) 'Trade Unionism and Globalization: Thoughts from Latin America' Current Sociology 50(1): 57-74.

Kelly, J (2005) 'Social Movement Theory and Union Revitalization in Britain' in S. Fernie and D. Metcalf (Eds.) Trade Unions: Resurgence or Demise? London: Routledge, pp. 62-82. 
Kiely, R (2003) 'The Race to the Bottom and International Labor Solidarity' Review: A Journal of the Fernand Braudel Centre 26(1): 67-88.

Kimmerling, B (1995) Between State and Society: The Sociology of Politics Tel Aviv: Open University [in Hebrew].

Latham, J. M and W. E. Dizler (2010) 'Collective Effort: The American Union and the American Public Library’ Library Trends 59(1-2): 237-255, 374-375.

Mangum, G. L and S. L. Mangum (1993) 'Assessing Alternative Employment-Relations Systems' Challenge 36(4): 29-37.

Margalit, E (1994) Trade Unions in Israel Past and Present: Status in the Histadrut Union and in Society Tel Aviv: Ramot [in Hebrew].

McCartin, A. J, L. Compa and S. Friedman (2005) 'Democratizing the Demand for Workers’ Rights / A Response’ Dissent 52: 61-72.

Melling, J (2004) 'Leading the White-Collar Union: Clive Jenkins, the Management of Trade Union Officers and the Politics of the British Labour Movement c. 1968-1979' International Review of Social History 49: 71-102.

Miller, D (2005) 'Regional Solidarity and a New Regional Movement in PostApartheid Southern Africa: Retail Workers in Mozambique and Zambia' Labour, Capital and Society 38(1/2): 94-125.

Pierce, M (2000) 'The Populist President of the American Federation of Labor: The Career of John McBride, 1880-1895' Labor History 41: 5-24.

Rainnie, A (2006) 'The Future of Worker Representation' Capital and Class 30(2): 169-174.

Ramon, H (1994-5) Minutes of Histadrut chairman's report Elected Representatives of the Histadrut, July 1994-November 1995, p. 3.

Ramon, H (1995) The Histadrut - The Sinking Titanic Histadrut, unpublished internal document [in Hebrew].

Rao, B. S (2004) 'New Social Forces in India' Foreign Affairs 23(4): 635-643.

Reinhart, T (1999) 'How the Histadrut was destroyed' Mit'an 10: 1-3 [in Hebrew].

Riddell, N (2000) 'Walter Citrine and the British Labour Movement, 1925-1935' History 85(278): 285-288.

Shapiro, Y (1977) Israeli Democracy Ramat-Gan, Israel: Massada [in Hebrew].

Shostak, B. A (2006) 'Finding Meaning in Labor's "Perfect Storm": Lesson from the 1981 PATCO Strike' Employee Responsibilities and Rights Journal 18(3): 223-229.

Shvarts, S (2002) The Workers' Health Fund in Eretz Israel: Kupat Holim, 1911-1937 New York: University of Rochester.

Shvarts, S (2008) Health and Zionism New York: University of Rochester. 
Simms, M (2007) 'Interest Formation in Greenfield Union Organizing Campaigns' Industrial Relations Journal 38(5): 439-54.

Stirling, J (2005) 'There's a New World Somewhere: The Rediscovery of Trade Unionism' Capital and Class 29(3): 43-63.

Taylor, P and P. Bain (2003) 'Call Centre Organizing in Adversity: From Excell to Vertex' in G. Gall (Ed.) Union Organizing: Campaigning for Trade Union Recognition London: Routledge, pp: 153-172.

Voss, K and R. Sherman (2000) 'Breaking the Iron Law of Oligarchy: Union Revitalization in the American Labor Movement' American Journal of Sociology 106(2): 303-349.

Western, B (1995) 'A Comparative Study of Working-Class Disorganization: Union Decline in Eighteen Advanced Capitalist Countries' American Sociological Review 60(2): 179-201.

Weil, D (2005) 'A Strategic Choice Framework for Union Decision Making' Working USA 8(3): 327-347.

Willis, R (1988) 'Can American Unions Transform Themselves?' Management Review 77(2): 14-21. 